\title{
INVESTIGATION OF REED AND BULRUSH PREPARATION AND USAGE FOR ENERGY PURPOSES AND DETERMINATION OF BIOFUEL PROPERTIES AND HARMFUL SUBSTANCE EMISSIONS
}

\author{
Algirdas Jasinskas $^{1}$, Rolandas Domeika ${ }^{1}$, Egle Jotautiene ${ }^{1}$, Jiri Masek ${ }^{2}$, Dionizas Streikus ${ }^{1}$ \\ ${ }^{1}$ Vytautas Magnus University, Lithuania; ${ }^{2}$ Czech University of Life Sciences Prague, Czech Republic \\ algirdas.jasinskas@vdu.lt, rolandas.domeika@vdu.lt, egle.jotautiene@vdu.lt, masekj@tf.czu.cz, \\ dionizasstreikus@gmail.com
}

\begin{abstract}
Fossil fuel resources are rapidly decreasing every year, and the consumption of this fuel leads to the environmental pollution and the increase in greenhouse gas emissions. For this reason, renewable energy sources, such as woody and herbaceous plants, are also supplied to the energy market. In this article the newest scientific-technical information was analysed about non-traditional grass plants, such as reed and bulrush. The experiment was established and research was carried out at the Vytautas Magnus University Agriculture Academy (VMU AA), Institute of Agricultural Engineering and Safety, Lithuania. Plants were grown and harvested in Lithuania and were processed and used for energy purposes, overlooked their preparation for biofuel and burning technological and technical solutions. The analyses of reed and bulrush utilization for energy purposes possibilities were performed and experimental research results presented for their preparation and use for energy conversion (burning). There were presented the research results of reed and bulrush preparation for biofuel - milling and pellet production, and also the pellet elemental composition, ash content, calorific value, was determined and effect on environment was evaluated while burning reed and bulrush pellets. For comparison, wood sawdust pellets were also investigated. The pellet density of reed reached $1178.9 \mathrm{~kg} \mathrm{~m}^{-3} \mathrm{dry}$ matter (DM), the ash content of reed and bulrush was 3.2\% and 5.9\%, respectively. Research investigations were done using a small capacity $(5 \mathrm{~kW})$ solid biofuel boiler in which granulated biofuel was burned. The harmful gas emissions to the environment - carbon dioxide $\mathrm{CO}_{2}$, carbon monoxide $\mathrm{CO}$, nitrogen oxides $\mathrm{NO}_{\mathrm{x}}$ and the amount of carbon and nitrogen combinations $\mathrm{C}_{\mathrm{x}} \mathrm{H}_{\mathrm{y}}$ in burning products were investigated and assessed. It was determined that when reed and bulrush pellets were burned, the harmful emissions to the environment did not exceed the permissible norms. The received research results were compared with the results of other scientists, who assessed various sorts of non-traditional herbaceous plant granulated biofuel properties and impact to the environment while plant burning.
\end{abstract}

Keywords: renewable energy, unconventional plants, biomass processing, burning.

\section{Introduction}

Biomass has been widely recognized worldwide as a trustworthy renewable and sustainable energy source. Biomass particles can be compacted into cylindrical pellets - the main type of solid fuels [1].

At present, fossil fuels are still the most widely used source of fuel: nearly $86 \%$ of the total energy consumption comes from fossil fuels. Replacing fossil fuel with biomass will have positive effects on environment $[2 ; 3]$.

The energy sector is important for every country, even for as small as Lithuania. Here, fossil fuel resources are very limited, therefore it is necessary to look for alternative fuels and thus increase the country's energy independence. One of most popular alternative energy sources in Lithuania is biofuel: raw material produced from biomass waste. The most well-known and widespread biofuel in Lithuania and other countries is wood biomass fuel; however, a rising need to save wood resources is forcing the search for alternatives.

One of the suitable wood substitutes can be reed. Previous research has shown that dry reed can be a precious fuel: it is burnable, its calorific value does not exceed that of straw and is almost equal to the calorific value of wood waste (dry reed calorific value $-17.9 \mathrm{MJ} \cdot \mathrm{kg}^{-1}$, straw calorific value 16.5 MJ $\cdot \mathrm{kg}^{-1}$, wood chip calorific value $-19 \mathrm{MJ} \cdot \mathrm{kg}^{-1}$ ) [4]. This topic is not new, but very relevant for Lithuania and other European countries with similar climatic conditions, because it is important to realise the resources that are possible and which can be best used for fuel production. In order to investigate the use of reeds for biofuel and their suitability for energy conversion, it is necessary to do circumstantial research using appropriate methodology and implements [5]. 
Atmospheric carbon dioxide $\left(\mathrm{CO}_{2}\right)$ concentrations have increased from approximately $270 \mathrm{ppm}$ in pre-industrial times to over $400 \mathrm{ppm}$ in recent times, and these values are expected to increase to $450 \mathrm{ppm}$ by 2030 due to combustion of fossil fuels and changes in usage [6].

Wood, straw and energy crops is one of the most important renewable energy sources in Europe and Lithuania and now accounts for a considerable share of the local fuel [7]. Recent advances in biomass feedstock development and conversion technologies have created new opportunities for using agricultural land as a means of producing these renewable fuels in larger quantities than relying on wood and agricultural residues alone [8].

Currently in Europe, only about $7 \%$ of energy comes from renewable sources. The European Union imports about $48 \%$ of its energy from Russia and Norway. The 2006 EU Sustainable Development Strategy predicted that renewable energy production would reach $20 \%$ in 2020 . In the $20^{\text {th }}$ century in Lithuania, only $15 \%$ of energy production comes from renewable sources [9]. It is planned that by 2020, the heat generation from solid biofuel in Lithuania will reach $67 \%$ [10].

Biomass is the most perspective source of renewable energy. Increasing concerns about climate change mitigation and rising oil prices have led to unprecedented interest in the development of costeffective and convenient renewable fuels in recent years, and pelleting has become the most used technology for biomass processing [11].

Reed (Phragmites australis) is the plant of the grass family. It grows in wetlands, on river and lake banks, in swamps and road trenches, and reaches $100 \mathrm{~cm}-400 \mathrm{~cm}$ tall. Very important reed plantations in Lithuania grow on the shores of the Curonian Bay. Young plants are high in protein and sugar, making them liked by cattle. However, as they grow rapidly, the nutrition of these plants drops dramatically, they become very hard and not appealing to animals [12].

Bulrush (Typha) is a cattail (Typhaceae) family plant. It has a creeping thick rhizome, high in starch. Flowers are concentrated in ears. It has two kinds of roots: one - long, to help anchor to the soil, and second - short, to soak. These plants grow in swamps and on slow running water banks up to $1.5 \mathrm{~m}$ deep. The starch-rich rhizomes are used for food and human medicine [13]. The areas of reed and bulrush in Lithuania are large, about 300-400 ha of these plants could be used for the biofuel production.

In order to understand the suitability of any raw material for energy production, it is important to determine the ultimate analysis as the basic composition of the raw material [14]. Carbon, nitrogen, hydrogen and oxygen are the main chemical components of solid fuels. Fixed carbon represents the quality of carbon trapped in biomass by the photosynthetic process: the higher the content of fixed carbon, the higher the quality of biomass, as it increases the heating value [15].

The aim of this study - to determine the technological-technical, energy and environmental parameters of reedy plant chopping, milling, pellet preparation and utilization as solid biofuel.

\section{Materials and methods}

\section{Raw material preparation and pellet production}

Research on the preparation and use of biofuels for energy conversion by reed plants was carried out in 2017-2019 in Lithuania, at the Vytautas Magnus University Agriculture Academy, Institute of Agricultural Engineering and Safety. The reeds and bulrush used for the experimental research were harvested during the winter season from the shore of the lake in Kaunas district, the harvested plants were tied in 1.5-2.0 kg bundles, and 10 reed and bulrush bundles were prepared for experimental studies.

Before the production of granular biofuel, the bundles of reeds and bulrush were chopped with a drum chopper and milled into flour with a fineness of $1-2 \mathrm{~mm}$ by a hammer mill. To produce pellets, a small capacity granulator "Peleciarka" of $7.5 \mathrm{~kW}$ with a horizontal granulator matrix was used (produced 2011 by Company POLEXIM, Poland). The diameter of the pellets was $6 \mathrm{~mm}$.

The pressing productivity of the granulator was $250-350 \mathrm{~kg} \cdot \mathrm{h}^{-1}$. Pellet moisture content, ash content, and calorific values were set. Before the ground mass entered the granulator, it was mixed thoroughly to achieve homogeneity. Then, the raw material was moistened (if it was too dry for granulation), a certain dosage was supplied to the press chamber, where in the mill it was moved by 
rollers through the matrix holes of $6 \mathrm{~mm}$ diameter. The biomass was pressed through the holes to form pellets.

\section{Determination of pellet moisture content}

Pellet moisture content was determined in an oven of a laboratory drying chamber, according to the standard method. Pellet volume was calculated by the measurements of the pellet size (diameter and length). After that, the pellet density was calculated.

\section{Determination of pellet elementary composition, calorific value and ash content}

Pellet elementary composition and ash content were determined at the Lithuanian Energy Institute (LEI) Thermal Equipment Research and Testing laboratory in accordance to the following valid Lithuania and the EU countries standard methodology:

- using the basic element analyser Flash 2000, No. 2011 F0055;

- according to LST EN 14774-1:2010 standard, in moisture test rig No. 8B/1;

- according to LST EN 14775:2010 standard, in ash content test rig No. 8B/5.

The calorific value $\left(\mathrm{MJ} \cdot \mathrm{kg}^{-1}\right)$ of the plant chaff was determined by a C 2000 calorimeter (IKA, Germany) and the standard methodology (BS EN 14918:2009).

\section{Determination of harmful emissions}

Fuel burning efficiency and harmful emissions depend on the type of fuel, fuel quality, and shape of boilers fired with solid biofuels. In order to understand the influence of these parameters on the formation of pollutants, an investigation was carried out in a low power $(5 \mathrm{~kW})$ solid-fuel boiler at the Thermal Equipment Research and Testing laboratory of the Lithuanian Energy Institute. The pollutants were measured with the flue gas analysers DATATEST 400 CEM and VE7, during the burning process.

The total carbon, hydrogen, nitrogen, sulphur and oxygen quantities were measured according to the requirements of the standard EN 15104:2010. The pellet samples $(5 \mathrm{~kg})$ were delivered to the laboratory, where combustion and emission testing was performed. The combustion took 8-10 min. for each sample. When the emissions of harmful substances into the environment were estimated, they were compared to the parameters of other energy plant granulated biofuels.

In experimental studies, each experiment was repeated 3-5 times. Research data were statistically evaluated by one-factor dispersion analysis, correlation and regression methods. ANOVA software was used to determine the boundaries of the fundamental difference between the probability levels of R05 and R01 according to P criterion [16].

\section{Results and discussion}

\section{Pellet density and elemental composition}

The pellet density of the reeds was analysed and proven to be sufficient enough; it reached the following numbers: for reed $-1178.9 \mathrm{~kg} \cdot \mathrm{m}^{-3} \mathrm{DM}$ (dry matter), for bulrush $-1050.0 \mathrm{~kg} \cdot \mathrm{m}^{-3} \mathrm{DM}$ and for wood $1100.9 \mathrm{~kg} \cdot \mathrm{m}^{-3} \mathrm{DM}$.

The determined pellet elemental composition is presented in Table 1.

Elemental composition of reedy plant pellets

Table 1

\begin{tabular}{|c|c|c|c|c|c|c|}
\hline \multirow{2}{*}{$\begin{array}{c}\text { Type of } \\
\text { biofuel }\end{array}$} & $\mathbf{C}$ & $\mathbf{O}$ & $\mathbf{H}$ & $\mathbf{S}$ & $\mathbf{N}$ & Cl \\
\cline { 2 - 7 } & $\mathbf{C}$ & 42.25 & $0.44 \pm 0.32$ & $0.05 \pm 23.13$ & $5.56 \pm 0.45$ & 0.11 \\
\hline Reed pellets & $48.48 \pm 1.16$ & $4.67 \pm 0.39$ & $0.01 \pm 0.01$ & $1.10 \pm 0.35$ & 0.05 \\
\hline Bulrush pellets & $47.50 \pm 0.35$ & 39.85 & $5.67 \pm 0.05$ & 0.01 & 0.01 & 0.06 \\
\hline Wood pellets & $49.53 \pm 1.10$ & 43.59 & $5.75 \pm 0.05$ &
\end{tabular}

According to our investigation, bulrush and reed pellets contain three main components: carbon $(\mathrm{C})$, hydrogen $(\mathrm{H})$ and oxygen $(\mathrm{O})$, which together make $93 \%$ (in bulrush) of dry mass. In this way, bulrush differs very little from wood $(99 \%)$. The basic elemental composition of reed, bulrush consists of carbon $(\mathrm{C})$ and oxygen $(\mathrm{O})$ and one the third element, which is different - nitrogen $(\mathrm{N})$, was found in reed pellets in $5.56 \%$. 


\section{Pellet moisture content, ash content and calorific value}

The determined pellet moisture content, ash content and calorific value are presented in Table 2. The moisture content of bulrush pellets reached $10.79 \%$ and was higher than that of reed, however, all of these results fully met the requirements for granulated biofuel.

From the results shown in Table 2, we can see that the smallest ash content was determined in reed pellets $(3.17 \%)$. To compare these results with wood biofuel results, the ash content of the former is almost twice higher. Determined calorific value of reed pellets was $17.86 \mathrm{MJ} \cdot \mathrm{kg}^{-1}$. This calorific value is bigger than that of willow $\left(17.63 \mathrm{MJ} \cdot \mathrm{kg}^{-1}\right)$, but about $2 \%$ lower than that of birch, which is the standard biofuel, used in many countries [7].

Moisture content, ash content and calorific value of reedy plant pellets

Table 2

\begin{tabular}{|c|c|c|c|}
\hline Type of biofuel & Moisture content \% & Ash content \% & Calorific value MJ·kg $^{-1}$ \\
\hline Reed pellets & $6.32 \pm 0.02$ & $3.17 \pm 0.13$ & $17.86 \pm 0.31$ \\
\hline Bulrush pellets & $10.79 \pm 0.07$ & $5.88 \pm 0.06$ & $17.47 \pm 0.43$ \\
\hline Wood pellets & $2.34 \pm 0.07$ & $1.13 \pm 0.03$ & $18.63 \pm 0.33$ \\
\hline
\end{tabular}

For comparison we provide the results of other researchers, which have also investigated the properties of fibrous hemp Bialobrzeskie. The calorific value of Bialobrzeskie was $\mathrm{Q}=15.03$ 16.14 MJ $\mathrm{kg}^{-1}$. The ash content reached $1.5-2.7 \%$, and determined at the beginning of ash deformation in the samples was $t_{d}=710-850{ }^{\circ} \mathrm{C}$. Other melting temperatures exceeded $1500{ }^{\circ} \mathrm{C}$ [17].

\section{Emissions from pellet combustion}

The investigations of harmful gas emissions from burning reed, bulrush, and reed canary grass were performed in the Lithuanian Energy Institute. As mentioned in the methodology of this study, while burning, pellets emit harmful emissions, which are shown in Table 3.

Table 3

\section{Harmful gas emissions of reedy plants}

\begin{tabular}{|c|c|c|c|c|}
\hline Type of biofuel & $\mathbf{C O}_{\mathbf{2}} \mathbf{\%}$ & $\mathbf{C O} \mathbf{~ p p m}$ & $\mathbf{N O}_{\mathbf{x}} \mathbf{p p m}$ & $\mathbf{C}_{\mathbf{x}} \mathbf{H}_{\mathbf{y}} \mathbf{~ p p m}$ \\
\hline Reed pellets & 4.3 & 234.0 & 83.9 & 23.7 \\
\hline Bulrush pellets & 4.5 & 570 & 173.6 & 40.2 \\
\hline Wood pellets & 4.4 & 10 & 137.8 & 49.5 \\
\hline
\end{tabular}

After burning of the investigated pellets, it was determined that all of these plants had similar $\mathrm{CO}_{2}$ emissions. When burning reed plant pellets harmful gas emissions reached these values: $\mathrm{CO}_{2}-4.3 \%$, $\mathrm{CO}-234.0 \mathrm{ppm}, \mathrm{NO}_{\mathrm{x}}-83.9 \mathrm{ppm}$ and $\mathrm{C}_{\mathrm{x}} \mathrm{H}_{\mathrm{y}}-23.7 \mathrm{ppm}$. All these harmful gas emissions were lower than burning bulrush pellets. Nonetheless, none of the investigated plants exceeded the maximum permissible levels of harmful emissions.

For comparison, we will present data from other researchers who have investigated the efficiency and harmful emissions of burning various types of pellets of non-traditional energy plants. For example, the investigations of Malatak and Passian showed that the emissions of giant knotweed pellets were significantly higher than those of fibrous plant pellets: the $\mathrm{CO}$ concentration was $928.9 \mathrm{mg} \cdot \mathrm{m}^{-3}$ and the $\mathrm{NO}_{\mathrm{x}}$ concentration was $297.0 \mathrm{mg} \mathrm{m}^{-3}$ [18].

Researchers from the USA and Poland have determined the $\mathrm{NO}_{\mathrm{x}}$ concentration of wood biomass, which was $170 \mathrm{mg} \mathrm{m}^{-3}$ [19]. Other researchers have estimated that the CO concentration of peat was $140 \pm 297 \mathrm{mg} \cdot \mathrm{MJ}^{-1}$ and the $\mathrm{NO}_{\mathrm{x}}$ concentration was $225 \pm 29 \mathrm{mg} \cdot \mathrm{MJ}^{-1}$ [20]. Finnish scientists investigated a mixture of wood and reed canary grass pellets: the $\mathrm{CO}$ concentration was $9.6 \pm 3.1 \mathrm{mg} \cdot \mathrm{MJ}^{-1}$ and the $\mathrm{NO}_{\mathrm{x}}$ concentration was $212 \pm 17 \mathrm{mg} \cdot \mathrm{MJ}^{-1}[21]$.

\section{Conclusions}

1. The research results of biometrical parameters of reed and bulrush pellets showed that these plants had different moisture content. The moisture content of bulrush pellets was the highest $10.79 \pm 0.07 \%$, whereas that of reed pellets was almost twice as low $-6.32 \pm 0.02 \%$. 
2. After investigation of the elemental composition and the biofuel calorific value of three plant pellets, it can be stated that the reed calorific value was sufficiently high and reached $17.86 \pm 0.31$ $\mathrm{MJ} \cdot \mathrm{kg}^{-1}$, it is only $4 \%$ less than wood pellets.

3. When burning reed plant pellets, it was determined that all harmful gas emissions were less than for bulrush pellets, they reached the values: $\mathrm{CO}_{2}-4.3 \%, \mathrm{CO}-234.0 \mathrm{ppm}, \mathrm{NO}_{\mathrm{x}}-83.9 \mathrm{ppm}$, $\mathrm{C}_{\mathrm{x}} \mathrm{H}_{\mathrm{y}}-23.7 \mathrm{ppm}$.

4. To sum up the results of the presented study, it should be concluded that reed plants can be used as granulated biofuel, as the pellets of these plants meet the requirements of high quality biofuel. In addition, these plants can be used as waste, since there is no need to plant, fertilize and grow them.

\section{References}

[1] Maria T.C., Pantaleo A., Pellerano, A. Influence of process parameters and biomass characteristics on the durability of pellets from the pruning residues of Olea europea L. Biomass Bioenergy, vol. 35, 2011, pp. 402-410. DOI:10.1016/j.biombioe.2010.08.052.

[2] Poddar S., Kamruzzaman M., Sujan M., Hossain M., Jamal M.S., Gafur M.A., Khanam M. Effect of compression pressure on lignocellulosic biomass pellet to improve fuel properties: higher heating value. Fuel, vol. 131, 2014, pp. 43-48. DOI:10.1016/j.fuel.2014.04.061.

[3] Spath P.L.; Mann M.K. Coal versus biomass electricity generation - comparing environmental implications using life cycle assessment. National Renewable Energy Laboratory, 1997.

[4] Sakalauskas A., Jasinskas A., Šarauskis E., Vaiciukevičius E., Kalinauskaitè S., Simonaitis P. Perennial grasses and non-traditional herbaceous plants (miscanthus, sida, cup plant and reedy grasses) and its mixtures usage for production of pressed biofuel. Agriculture, food and fishery MTTV project final report. 2014, 68 p. (In Lithuanian).

[5] Kakitis A., Nulle I., Ancans. D. Mechanical properties of composite biomass briquettes, Environmental. Technology. Resources. Proceedings of the 8th international scientific and practical conference, vol. 1, 2011, pp. 175-183. DOI: 10.17770/etr2011vol1.898.

[6] IPCC. Climate Change 2014 Mitigation of Climate Change: Working Group III Contribution to the Fifth Assessment Report of the Intergovermental Panel on Climate Change. Cambridge University Press. New York, NY, USA, 2014.

[7] Sakalauskas A. Substantiation of plant biomass (straw, grasses, woody plants, etc.) harvesting and preparation of biofuel technologies. Final report, Akademija, 2012, pp 108. (In Lithuanian).

[8] Macak M., Nozdrovicky L., Hussein O.A. Effect of preheating and different moisture content of input materials on durability of pellets made from different phytomass content. Acta Technologica Agriculturae, vol. 1, 2015, pp. 22-27. DOI: 10.1016/j.aninu.2016.05.002.

[9] Janisevičius G. Wood and agro-biofuel. Sustainable development strategy and practice. Research work, 2014, 143 p.

[10] Verbickas D., Juknys R., Kleišmantas A. The use of solid biofuels in Lithuania for heat production, future prospects and the impact on the environment. Energetika, vol. 59(3), 2013, 144 p. (In Lithuanian).

[11] McKendry P. Energy production from biomass (part 1): overview of biomass. Bioresource Technology, vol. 83, 2002, pp. 37-46. DOI: 10.1016/S0960-8524(01)00118-3.

[12] Reed. [online] [13.09.2019]. Available at: https://lt.wikipedia.org/wiki/Paprastoji_nendrè. (In Lithuanian).

[13]Bulrush. [online] [13.09.2019]. Available at: https://lt.wikipedia.org/wiki/Švendras. (In Lithuanian).

[14] Yin C.Y. Prediction of higher heating values of biomass from proximate and ultimate analyses. Fuel, vol. 90, 2011, pp. 1128-1132. DOI: 10.1016/j.fuel.2010.11.031.

[15] Jolliet O., Margni M., Charles R., Humbert S., Payet J., Rebitzer G., Rosenbaum R. IMPACT $2002+$ : A new life cycle impact assessment methodology. Int J LCA, vol. 6, 2003, pp. 324-330.

[16] Tarakanovas P., Raudonius S. Statistical analysis of agronomic research data using computer programs ANOVA, STAT, SPLIT-PLOT from the package SELEKCIJA and IRRISTAT. Akademija, Kèdainiai distr., 2012, 58 p. 
[17] Poisa L., Adamovics A. Evaluate of hemp (Cannabis sativa L.) quality parameters for bioenergy production. Engineering for rural development, Proceedings of the 10th international scientific conference, Jelgava, 2011, pp. 358-362.

[18] Malatak J., Passian L. Heat-emission analysis of small combustion equipments for biomass. Research in agricultural engineering, vol. 57, 2011, pp. 37-50.

[19] Higgins B., Yan L., Gadalla H., Meier J., Fareid T., Liu G., Milewicz M., Repczynski A., Ryding M., Blasiak W. Biomass co-firing retrofit with ROFA for NOx reduction. Pol.J.Environ.Stud., vol. 19(6), 2010, pp. 1185. DOI: 10.15244/pjoes/99106.

[20] Krugly E., Martuzevicius D., Puida E., Buinevicius K., Stasiulaitiene I., Radziuniene I., Minikauskas A., Kliucininkas L. Characterization of gaseous- and particle-phase emissions from the combustion of biomass-residue-derived fuels in a small residential boiler. Energy and fuels, vol. 28, 2014, pp. 50-57.

[21] Sippula O., Lamberg H., Leskinen J., Tissari J., Jokiniemi J. Emissions and ash behavior in a 500 $\mathrm{kW}$ pellet boiler operated with various blends of woody biomass and peat. Fuel, vol. 202, 2017, pp. 144. DOI: 10.1021/ef401267t. 